\title{
Cytokine gene expression in skin and lymphoid organs in graft versus host disease
}

\author{
A W Rowbottom, J Norton, P G Riches, J R Hobbs, R L Powles, J P Sloane
}

\begin{abstract}
Aim-To determine if human graft versus host disease (GvHD) is associated with any detectable change in cytokine gene expression in the skin and lymphoid organs.
\end{abstract}

Methods-Reverse transcriptase and the polymerase chain reaction were used to amplify mRNA for interleukins-1 (IL-1), -2 (IL-2), -4 (IL-4) and -6 (IL-6), IL-2 receptor (IL-2R), tumour necrosis factors $\alpha(\mathrm{TNF}-\alpha)$ and $\beta(\mathrm{TNF}-\beta)$, gamma interferon (IFN $\gamma$ ) and granulocyte macrophage colony stimulating factor (GM-CSF) in frozen punch biopsy specimens of skin and necropsy samples of skin, lymph node, and spleen.

Results-No cytokine mRNA was detected in the punch biopsy specimens except weak signals for IL-6 and IL-1 and GMCSF in two normal donors and IL2-R in one patient with GvHD. In samples of skin taken at necropsy, however, significant quantities of mRNA for TNF- $\alpha$, TNF- $\beta$, and IL-4 were detected in patients who had or had had GvHD in contrast to those without the disease whose skin lacked mRNA for these products but contained detectable quantities of IL-1, IL2-R, IL-6 and GM-CSF. There seemed to be a reciprocal relation between TNF- $\alpha$ and IL-4. In necropsy samples of lymph node and spleen a pattern of cytokine production similar to that in the skin was observed with a preponderance of TNF- $\alpha$, TNF- $\beta$ and IL- 4 in patients with GvHD and GM-CSF and IL-6 in those without the disease.

Conclusions-The local synthesis of these molecules would explain many of the morphological and immunohistological features of GvHD. The failure to detect TNF- $\alpha$, TNF- $\beta$, and IL-4 in skin biopsy specimens exhibiting GvHD is probably due to their small size but further investigations are required.

(F Clin Pathol 1993;46:341-345)

Graft versus host disease (GvHD) is a major complication of bone marrow transplantation (BMT) resulting in significant morbidity and mortality. ${ }^{1}$ It can be prevented by depleting the donor marrow of $\mathrm{T}$ lymphocytes, ${ }^{2}$ but this procedure results in an increased incidence of marrow failure ${ }^{3}$ and leukaemic relapse. ${ }^{4}$ The mechanisms by which $\mathrm{T}$ cells produce dam- age to the affected tissues are not clear.

The skin is the most extensively studied tissue as it is the most frequently involved and the most easy to biopsy. The changes typically take the form of a lichenoid dermatitis with vacuolation and individual cell necrosis of the basal layer of the epidermis, accompanied by lymphocytic infiltration of the upper dermis and lower epidermis. ${ }^{5}$ In the early stages of the disease, however, the leucocytic infiltrate may be absent indicating that it is a secondary event. ${ }^{6}$

Immunohistological studies have shown that cutaneous GvHD is accompanied by an increase in the expression of class II major histocompatibility complex (MHC) antigens on lymphocytes and keratinocytes and the adhesion molecules ICAM-1, VCAM-1, and ELAM-1 on keratinocytes, dermal dendritic cells, and endothelial cells, respectively. ${ }^{8-11}$ Although increased expression of HLA-DR on keratinocytes and VCAM-1 on dermal dendritic cells may precede the appearance of a lymphocytic infiltrate, demonstrable increases in ICAM-1 and ELAM-1 are generally only seen when an infiltrate is present. ${ }^{9-11}$ Increased expression of these molecules may be induced on a number of cell types in culture by the addition of various cytokines.

Cytokines are potent soluble mediators of inflammatory and immune responses, being produced by a wide variety of cell types. ${ }^{12}$ Interleukin-1 (IL-1), interleukin-2 (IL-2), interleukin-4 (IL-4), interleukin-6 (IL-6), tumour necrosis factor (TNF) and interferon $\gamma$ (IFN $\gamma$ ) have been shown to increase immune responses, leading to the recruitment, activation, and proliferation of lymphocytes. ${ }^{13}$ In vitro, stimulation of lymphocytes with alloantigens has shown that TNF- $\alpha$ and $\beta$, IL-2, and IFN $\gamma$ were produced by responding cells. ${ }^{14}$ While suggesting the role cytokines may have in $\mathrm{GvHD}$, these results remain to be confirmed in vivo.

In the period after transplantation serum concentrations of cytokines show poor temporal correlation with the clinical manifestations of $\mathrm{GvHD}$, although as a group patients with GvHD have significantly higher concentrations than patients without GvHD. ${ }^{15}$ Analysis of cytokine gene expression in mice given solid organ transplants has shown that TNF- $\beta$, IL- 4 , IFN $\gamma$ and IL- 2 may be associated with episodes of graft rejection. ${ }^{16}$ An early stage of GvHD may thus be the release of cytokines consequent on interactions between donor and recipient cells. The effects on MHC antigens and adhesion mole- 
Table 1 Relative gene expression detected in skin punch biopsy specimens

\begin{tabular}{|c|c|c|c|c|c|c|c|c|c|c|c|c|c|}
\hline \multirow{2}{*}{$\begin{array}{l}\text { Case } \\
\text { No }\end{array}$} & \multirow[b]{2}{*}{ Age } & \multirow[b]{2}{*}{ Sex } & \multirow{2}{*}{$\begin{array}{l}\text { Days } \\
\text { After } \\
B M T\end{array}$} & \multicolumn{10}{|c|}{ Cytokine } \\
\hline & & & & $\beta$-actin & $I L-2 R$ & $I L-2$ & $I L-1$ & $I L-6$ & $T N F-\alpha$ & $T N F-\beta$ & $I F N \gamma$ & $I L-4$ & $G M-C S F$ \\
\hline \multicolumn{14}{|c|}{ Normal donors: } \\
\hline 1 & & & & +++ & - & - & + & - & - & - & - & - & + \\
\hline 2 & & & & +++ & - & - & - & - & - & - & - & - & - \\
\hline 3 & & & & +++ & - & - & - & + & - & - & - & - & - \\
\hline 4 & & & & +++ & - & - & - & - & - & - & - & - & - \\
\hline \multicolumn{14}{|c|}{ Cutaneous GvHD: } \\
\hline 5 & 39 & $\mathrm{~F}$ & 21 & ++ & - & - & - & - & - & - & - & - & - \\
\hline 6 & 16 & $M$ & 9 & ++ & - & - & - & - & - & - & - & - & - \\
\hline 7 & 36 & M & 14 & ++ & - & - & - & - & - & - & - & - & - \\
\hline 8 & 49 & $M$ & 39 & ++ & + & - & - & - & - & - & - & - & - \\
\hline 9 & 24 & $M$ & 33 & ++ & - & - & - & - & - & - & - & - & - \\
\hline 10 & 29 & $M$ & 41 & ++ & - & - & - & - & - & - & - & - & - \\
\hline
\end{tabular}

cules are likely to be due to local production, but the possibility that they originate in the lymphoid system cannot be excluded.

In this study we have therefore used a sensitive method-the polymerase chain reaction-to detect mRNA of various cytokines in skin biopsy specimens and necropsy samples of skin and lymphoid tissues in allogeneic marrow recipients with and without GvHD

\section{Methods}

Punch biopsy specimens ( $3 \mathrm{~mm}$ ) of skin were obtained from the posterior iliac crest of four normal donors at the time of bone marrow harvest, and from six allogeneic bone marrow transplant (BMT) recipients from the site of a rash typical of GvHD. Skin samples were also taken at necropsy from nine BMT recipients, five of whom had had GvHD as a contributory cause of death and four of whom had no evidence of GvHD. Clinical details are given in tables 1 and 2 .

Ten samples of spleen and six of lymph nodes were obtained from necropsies on 13 BMT recipients, seven of whom had evidence of GvHD at the time of death. The remainder had exhibited no evidence of GvHD. Clinical details are included in table 3. All necropsy material was obtained within 24 hours of

Table 2 Relative gene expression detected in necropsy skin samples

\begin{tabular}{|c|c|c|c|c|c|c|c|c|c|c|c|c|c|c|}
\hline \multirow{2}{*}{$\begin{array}{l}\text { Case } \\
\text { No }\end{array}$} & \multirow[b]{2}{*}{ Age } & \multirow[b]{2}{*}{ Sex } & \multirow{2}{*}{$\begin{array}{l}\text { Days } \\
\text { After } \\
\text { BMT }\end{array}$} & \multirow[b]{2}{*}{ Necropsy findings } & \multicolumn{10}{|c|}{ Cytokine } \\
\hline & & & & & $\beta$-actin & $I L-2 R$ & $I L-2$ & $I L-1$ & $I L-6$ & $T N F-\alpha$ & $T N F-\beta$ & $I F N \gamma$ & $I L-4$ & $G M-C S F$ \\
\hline \multicolumn{15}{|c|}{ Normal skin: } \\
\hline 11 & 20 & $\mathrm{~F}$ & 180 & CMV pneumonitis & +++ & - & - & - & - & - & - & - & - & - \\
\hline 12 & 34 & $\mathrm{~F}$ & 31 & Pulmonary oedema & +++ & - & - & - & - & - & - & - & - & + \\
\hline 13 & 31 & $\mathrm{~F}$ & 84 & CMV pneumonitis & +++ & + & - & - & + & - & - & - & - & + \\
\hline 14 & 28 & $\mathrm{~F}$ & 270 & Candidiasis & +++ & + & - & ++ & ++ & - & - & - & - & ++ \\
\hline \multicolumn{15}{|c|}{ Cutaneous GvHD: } \\
\hline 15 & 39 & $\mathrm{~F}$ & 70 & $\begin{array}{l}\text { Skin GvHD } \\
\text { CMV + Aspergillus } \\
\text { pneumonitis }\end{array}$ & +++ & - & - & - & - & ++ & ++ & - & - & - \\
\hline 16 & 25 & $\mathrm{~F}$ & 150 & Skin and liver GvHD & $++t$ & - & - & - & - & - & ++ & - & $+t$ & - \\
\hline 17 & 19 & $\mathbf{M}$ & 31 & $\begin{array}{l}\text { Skin GvHD } \\
\text { Cerebral haemorrhage }\end{array}$ & +++ & - & - & - & - & +++ & ++ & - & & - \\
\hline 18 & 9 & $\mathrm{~F}$ & 7 & Skin and liver GvHD & +++ & - & - & - & - & - & +++ & - & ++ & - \\
\hline 19 & 18 & $\mathbf{M}$ & 42 & Skin and liver GvHD & +++ & + & - & + & + & ++ & - & - & - & + \\
\hline
\end{tabular}

Table 3 Relative gene expression detected in necropsy spleen and lymph node samples

\begin{tabular}{|c|c|c|c|c|c|c|c|c|c|c|c|c|c|c|c|}
\hline \multirow{2}{*}{$\begin{array}{l}\text { Case } \\
\text { No }\end{array}$} & \multirow[b]{2}{*}{ Age } & \multirow[b]{2}{*}{$\operatorname{Sex}$} & \multirow{2}{*}{$\begin{array}{l}\text { Days } \\
\text { After } \\
B M T\end{array}$} & \multirow[b]{2}{*}{ Necropsy findings } & \multirow[b]{2}{*}{ Tissue } & \multicolumn{10}{|c|}{ Cytokine } \\
\hline & & & & & & $\beta$-actin & $I L-2 R$ & $I L-2$ & $I L-1$ & $I L-6$ & $T N F-\alpha$ & $T N F-\beta$ & $I F N \gamma$ & $I L-4$ & $G M-C S F$ \\
\hline \multicolumn{16}{|c|}{ No GvHD: } \\
\hline 20 & 32 & $\mathrm{~F}$ & 20 & Interstitial pneumonitis & Lymph node & +++ & - & - & - & +++ & - & - & - & - & ++ \\
\hline 21 & 27 & $M$ & 44 & Interstitial pneumonitis & Spleen & ++ & - & - & + & + & - & ++ & - & - & + \\
\hline 22 & 36 & $\mathrm{~F}$ & 45 & Candidiasis + CMV & Spleen & ++ & - & - & - & ++ & - & - & - & - & ++ \\
\hline 23 & 31 & $\mathbf{F}$ & 19 & Bacterial pneumonia & Spleen & +++ & - & - & - & ++ & - & - & - & - & ++ \\
\hline 14 & 28 & $\mathbf{F}$ & 270 & Candidiasis & Lymph node & +++ & - & - & - & - & - & - & - & - & ++ \\
\hline \multirow{2}{*}{\multicolumn{6}{|c|}{ Cinv priedinomis }} & ++ & + & & & & - & - & - & - & - \\
\hline & 18 & $M$ & 55 & Skin and liver and gut GvHD & Lymph node & +++ & + & $\mathrm{i} / \mathrm{s}$ & + & + & ++ & +++ & _- & _- & - \\
\hline 24 & 18 & M & 55 & Skin and liver and gut GvHD & Spleen & +++ & - & - & - & - & ++ & - & - & - & - \\
\hline 25 & 29 & $M$ & 150 & $\begin{array}{l}\text { Skin and liver GvHD } \\
\text { Candidiasis }\end{array}$ & Spleen & +++ & - & - & - & - & ++ & - & - & - & - \\
\hline 25 & 29 & M & 150 & $\begin{array}{l}\text { Skin and liver GvHD } \\
\text { Candidiasis }\end{array}$ & Lymph node & +++ & - & - & - & - & ++ & ++ & - & - & - \\
\hline 17 & 19 & $M$ & 31 & $\begin{array}{l}\text { Skin GvHD } \\
\text { Cerebral haemorrhage }\end{array}$ & Spleen & +++ & - & - & - & - & - & +++ & - & ++ & - \\
\hline 17 & 19 & $M$ & 31 & $\begin{array}{l}\text { Skin GvHD } \\
\text { Cerebral haemorrhage }\end{array}$ & Lymph node & +++ & - & - & - & - & ++ & +++ & - & - & - \\
\hline $\begin{array}{l}19 \\
18\end{array}$ & $\begin{array}{l}18 \\
9\end{array}$ & $\begin{array}{l}\mathrm{M} \\
\mathrm{F}\end{array}$ & $\begin{array}{l}42 \\
7\end{array}$ & $\begin{array}{l}\text { Skin and liver GvHD } \\
\text { Skin and liver GvHD }\end{array}$ & $\begin{array}{l}\text { Spleen } \\
\text { Spleen }\end{array}$ & $\begin{array}{l}+++ \\
+++\end{array}$ & - & $\bar{i} / \mathrm{s}$ & - & ${ }_{-}^{\cdot}$ & ++ & $\begin{array}{l}+++ \\
+++\end{array}$ & - & $\overrightarrow{+}+$ & - \\
\hline 26 & 33 & $\mathrm{M}$ & 49 & $\begin{array}{l}\text { Liver GvHD } \\
\text { Interstitial pneumonitis }\end{array}$ & Spleen & +++ & - & - & - & - & - & +++ & - & ++ & - \\
\hline 26 & 33 & $\mathbf{M}$ & 49 & $\begin{array}{l}\text { Liver GvHD } \\
\text { Interstitial pneumonitis }\end{array}$ & Lymph node & +++ & - & - & - & - & ++ & +++ & - & - & - \\
\hline
\end{tabular}


death. Each sample was divided in half, one half snap-frozen in liquid nitrogen and the other formalin fixed and paraffin wax embedded for histological examination.

\section{HISTOPATHOLOGICAL FINDINGS}

Skin biopsy specimens from normal donors showed no histological abnormality. Those from BMT recipients with a GvHD rash showed classic histological features with a mild lymphocytic infiltration of the upper dermis and lower epidermis associated with epidermal basal cell degeneration with individual keratinocyte necrosis. Keratinocytes showed increased staining for HLA-DR antigens and ICAM-1. VCAM-1 positive dendritic cells were present in the dermis and endothelial cells showed increased ELAM-1. Skin samples taken at necropsy from patients with GvHD had only a scanty, or no clinically important lymphocytic infiltrate, but pronounced epidermal keratinocyte necrosis and basal cell degeneration. These histological changes may have been exaggerated to some extent by changes following death but they were not seen in necropsy skin samples from BMT recipients who died without evidence of GvHD.

All necropsy lymph nodes were hypocellular with absent lymphoid follicles and dilated sinuses. The spleens from all BMT recipients were of lymphocytes and showed siderosis. No histological differences were seen between those patients who died with or without evidence of GvHD. The changes in the nodes and spleens were identical with those described previously. ${ }^{17} 18$

\section{AMPLIFICATION BY PCR}

Total RNA was isolated by a single step extraction method using guanidium thiocyanate. ${ }^{19}$ The integrity of the RNA was assessed by electrophoresis following glyoxal treatment in a $1 \%$ agarose gel stained with ethidium bromide. ${ }^{20}$

Total RNA was reverse transcribed in $30 \mu \mathrm{l}$ reaction volumes containing: $1-5 \mu \mathrm{g}$ of total RNA, $10 \mathrm{mM}$ deoxynucleotide triphosphate mixture (dNTP, Gibco BRL), $6 \mu l$ of

Table 4 PCR primer sequence and expected molecular weight of amplified cDNA product

\begin{tabular}{|c|c|c|}
\hline Cytokine & Primer sequence & $\begin{array}{l}\text { Molecular } \\
\text { weight } \\
\text { (base pairs) }\end{array}$ \\
\hline TNF- $\alpha$ & $\begin{array}{l}\text { 5' ATGAGCACTGAAAGCATGATCCGG 3' } \\
\text { 5' GCAATGATCCCAAAAGTAGACCTGCCC 3' }\end{array}$ & 695 \\
\hline TNF- $\beta$ & $\begin{array}{l}5^{\prime} \text { ATGACACCACCTGAACGTCTCTTC } 3^{\prime} \\
5^{\prime} \text { CGAAGGCTCCAAAGAAGACAGTACT } 3^{\prime}\end{array}$ & 610 \\
\hline IL-1 $\beta$ & $\begin{array}{l}\text { 5' ATGGCAGAAGTACCTAAGCTCGC 3' } \\
5^{\prime} \text { ACACAAATTGCATGGTGAAGTCAGTT 3' }\end{array}$ & 802 \\
\hline IL-2 & $\begin{array}{l}\text { 5' ATGTACAGGATGCAACTCCTGTGTT } 3{ }^{\prime} \\
\text { 5' GTTAGTGTTGAGATGATGCTTTGAC 3' }\end{array}$ & 458 \\
\hline IL-2 receptor & $\begin{array}{l}\text { 5' GCCATGCAGATGGCCATGCAATATGC 3' } \\
\text { 5' AGCTAGTTATGACGGATGATGACCAC 3' }\end{array}$ & 425 \\
\hline IL-4 & $\begin{array}{l}\text { 5' ATGGGTCTCACCTCCAACTGCT } 3{ }^{\prime} \\
\text { 5' CGAACAATTTGAATATTTCTCTCTCAT 3' }\end{array}$ & 456 \\
\hline IL-6 & $\begin{array}{l}\text { 5' ATGAACTCCTTCTCCACAAGCGC 3' } \\
5^{\prime} \text { GAAGAGCCCTCAGGCTGGACTG 3' }\end{array}$ & 628 \\
\hline GM-CSF & $\begin{array}{l}\text { 5' ATGTGGCTGCAGAGCCTGCTGC 3' } \\
\text { 5' CTGGCTCCCAGCAGTCAAAGGG 3' }\end{array}$ & 424 \\
\hline $\mathrm{IFN} \gamma$ & $\begin{array}{l}\text { 5' ATGAAATATACAAGTTATATCTTGGCTTT 3' } \\
\text { 5' GATGCTCTTCGACCTCGAAACAGCAT 3' }\end{array}$ & 494 \\
\hline$\beta$-actin & $\begin{array}{l}\text { 5' ATGGATGATGATATCGCCGCG 3' } \\
\text { 5' CTAGAAGCATTTGCGGTGGACGATGGAGGGGCC 3' }\end{array}$ & 1126 \\
\hline
\end{tabular}

$5 \times$ reaction buffer $(5 \times$ buffer: $250 \mathrm{mM}$ TRIS-Cl, pH 8.3, $300 \mathrm{mM} \mathrm{KCl}, 15 \mathrm{mM}$ $\mathrm{MgCl}_{2}$ and $50 \mathrm{mM}$ dithiotreitol), $1.5 \mu \mathrm{g}$ of oligo $\mathrm{dT}_{12-18 \mathrm{mer}}$ (Pharmacia, LKB), 40 units RNAse inhibitor (Pharmacia, LKB) and 600 units Moloney murine leukaemia virus reverse transcriptase (Gibco BRL). The reaction mixture was incubated for 1 hour at $37^{\circ} \mathrm{C}$. Volumes of $10 \mu \mathrm{l}$ were then removed for amplification of CDNA using specific primers. The reaction mixture for the PCR consisted of $100 \mathrm{ng}$ of each primer, $5 \mu \mathrm{l}$ of 10 $x$ reaction buffer $(10 \times$ buffer: $500 \mathrm{mM} \mathrm{KCl}$, $100 \mathrm{mM}$ TRIS-Cl, pH 8.5, $15 \mathrm{mM} \mathrm{MgCl}_{2}$ and $0.1 \%$ gelatin), $1.25 \mathrm{mM}$ of each nucleotide (dNTP) and $2 \cdot 5$ units of TAQ polymerase (Amersham). The volume was adjusted to $50 \mu \mathrm{l}$ with sterile distilled water and overlayed with $100 \mu \mathrm{l}$ of mineral oil. The DNA was amplified for 35 cycles on a thermal cycler (Perkin Elmer Cetus) at $94^{\circ} \mathrm{C}$ for 1 minute and 30 seconds, at $60^{\circ} \mathrm{C}$ for $2 \mathrm{~min}$ utes, and at $72^{\circ} \mathrm{C}$ for 3 minutes. At the end of the 35 cycles the products were extended for 10 minutes at $72^{\circ} \mathrm{C}$. For all experiments positive controls were included which consisted of RNA extracted from the peripheral blood mononuclear cells of volunteer donors stimulated in vitro. PCR primer sequences and the expected molecular weight of each cDNA product is shown in table 4 .

\section{Results}

A strong or moderately strong signal for $\beta$ actin cDNA was detected in all samples confirming the integrity of the RNA. Cytokine mRNA profiles are shown in tables 1,2 , and 3. To confirm that all fragments were derived from amplification of cDNA products, duplicate tests were analysed without the addition of reverse transcriptase. In these tests no PCR products were detected. The results were graded semiquantitatively from weak positive $(+)$ to strong positive $(+++)$, according to the fluorescence intensity of the ethidium bromide staining.

No cytokine mRNA was detected in any of the punch biopsy specimens of skin (table 1) except in those from two normal donors giving weakly positive $(+)$ signals for IL-6 or IL-1 and GM-CSF and one patient with GvHD giving a weakly positive (+) signal for IL-2 receptor (IL-2R). The size of the specimens was small and therefore an alternative source of material was investigated. Larger skin samples taken after death were analysed for the presence of cytokine mRNA (table 2).

Clinically important quantities of $\mathrm{mRNA}$ for TNF- $\alpha$, TNF- $\beta$, and IL-4 were detected in patients who had or had had GvHD in contrast to those without the disease whose skin lacked the mRNA for these products. There were, however, detectable quantities of GM-CSF in three patients, IL-6 in two, IL$2 \mathrm{R}$ in two and IL-1 in one. Representative results are shown in the figure. An interesting finding was that there seemed to be a reciprocal relation between TNF- $\alpha$ and IL-4 in the GvHD group. 

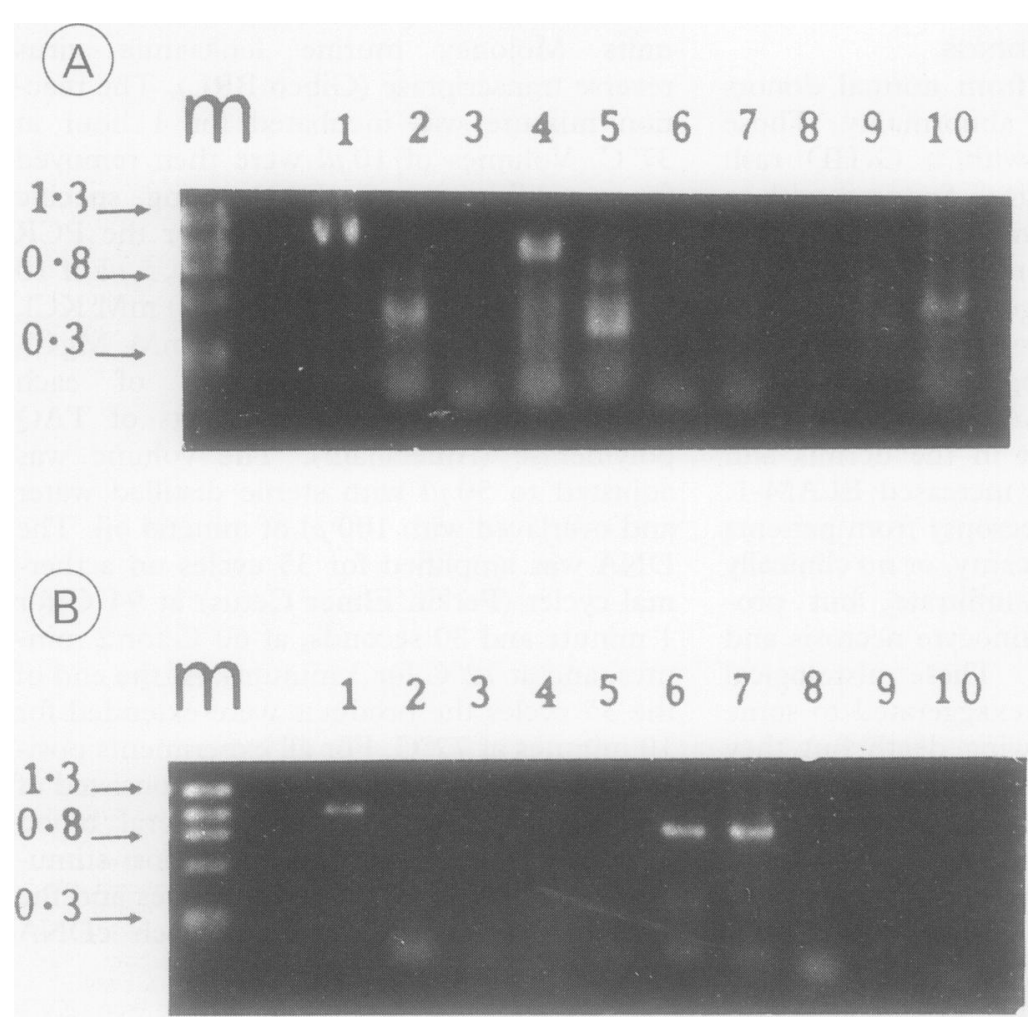

Representative patterns of cytokine gene expression in (A) non-GvHD and (B) GvHD skin biopsy specimens. Lanes $1 \beta$ actin; $2 I L-2 R ; 3 I L-2 ; 4 I L-1 ; 5 I L-6 ; T N F-\alpha ; 7$ TNF- $\beta ; 8$ IL-4; 9 IFN $\gamma$; and 10 GM-CSF. Lane M a Phi x 174 DNA/Hae III fragment molecular weight marker.

To investigate the discrepant findings between $2 \mathrm{~mm}$ punch biopsy specimens and the larger necropsy skin samples, $2 \mathrm{~mm}$ pieces were cut from additional frozen necropsy skin samples available from cases 15,16 , and 18 which had shown strong positive results by PCR for TNF- $\beta$ (table 2 ). A strong signal for $\beta$-actin $\mathrm{cDNA}$ was obtained in all three $2 \mathrm{~mm}$ necropsy samples but no TNF- $\beta$ mRNA was detected.

With the availability of other tissues taken at necropsy, it was also possible to investigate the production of the same cytokines in the lymphoid organs. A pattern of cytokine production similar to that seen in the skin was detected, with a preponderance of TNF- $\alpha$, TNF- $\beta$, and IL- 4 in patients with GvHD, and GM-CSF and IL-6 in those without the disease. As in the skin a reciprocal relation between TNF- $\alpha$ and IL-4 was seen.

\section{Discussion}

mRNA for TNF- $\alpha$, TNF- $\beta$, and IL-4 was detected in increased amounts in the skin and lymphoid organs in bone marrow transplant recipients who had died after GvHD. Surprisingly, necropsy samples retained the integrity of their RNA which was probably facilitated by the reduction in body tempera- ture until sampling and by the short time interval between death and necropsy. In contrast, similar necropsy tissues from marrow recipients without GvHD predominantly contained detectable amounts of IL-6 and GMCSF which were generally not found in the GvHD group. There therefore seems to be a reciprocal relation between these two pairs of cytokines in patients with and without GvHD. A further intriguing reciprocal relation was seen between TNF- $\alpha$ and IL-4 in the GvHD group. The nature and meaning of the associations between these molecules is not yet clear.

Cytokine mRNA was not detected in any of the punch biopsy specimens of skin exhibiting GvHD with the exception of one case in which small quantities of IL-2R were found. IL-2 receptors may be demonstrable on many of the infiltrating leucocytes in cutaneous GvHD. ${ }^{21}$ The reason for the low incidence of detection in our study is not certain but three factors may be important. First, all our patients received prophylactic cyclosporin which has been shown to block mRNA production for IL-2 and IL-2R. ${ }^{22}$ Second, the mRNA may be shortlived; Dallman et al have shown that mRNA for IL-2 is increased prior to organ rejection but rapidly disappears with increased immunosuppression. ${ }^{16}$ Third, the punch biopsy specimens may have been too small. This is also likely to explain our inability to detect TNF- $\alpha$, and IL- 4 as we were unable to detect TNF- $\beta$ mRNA in positive necropsy samples of skin if they were of comparable size with that of the punch biopsy specimens taken before death. Furthermore, the changes in various cytokine inducible molecules (increased HLA-DR, ICAM-1, VCAM-1 and ELAM-1) in the punch biopsy specimens provides circumstantial evidence for the presence of cytokine. One factor which can be excluded is leucocyte density which was actually lower in the necropsy samples.

There is good evidence to suggest that the cytokines we detected in the skin and lymphoid organs may be important in the pathogenesis of GvHD. Murine radiation chimeras have been shown to contain increased quantities of TNF- $\alpha$ mRNA in the spleen, lung, skin and gut ${ }^{23}$ and passive immunisation of these animals with anti-TNF antibody can reduce the cutaneous and intestinal lesions. ${ }^{24}$ Infusion of $T N F-\alpha$ into non-transplanted mice leads to the appearance of apoptotic cells in a number of tissues. ${ }^{25}$

The cytokines detected in this study are also known to induce the synthesis in vitro of molecules we observed on the same cell types in biopsy specimens showing GvHD. Thus ICAM-1 can be induced on cultured keratinocytes by the addition of TNF- $\alpha$ to the culture medium. ${ }^{26}$ More recently, IL-4 has been shown to increase VCAM-1 mediated T cell adhesion to cultured endothelial cells, an effect which can be increased if IL-4 is added in combination with TNF- $\alpha$ and TNF- $\beta$ (lymphotoxin). ${ }^{27}$ The expression of ELAM-1 on cultured endothelial cells can be increased 
by the addition of TNF- $\alpha .^{28}$

Furthermore, we have recently shown that the basal epidermal damage produced by GvHD precedes the lymphocytic infiltrate and have postulated that this damage, like the stimulation of HLA-DR and adhesion molecules, may be due to local cytokine release. ${ }^{7}$ TNF- $\alpha$ and TNF- $\beta$ have been shown to induce cytological abnormalities in cultured keratinocytes. ${ }^{29}$

It is not clear to what extent the presence of mRNA for TNF- $\alpha$, TNF- $\beta$, and IL- 4 in the skin and lymphoid tissues is of pathogenetic importance. We are currently looking for mRNA in a variety of necropsy tissues to determine if the expression of these cytokine genes is associated with morphological evidence of tissue damage and immunostaining for class II MHC antigens and adhesion molecules.

Localisation of TNF and IL-4 by immunohistology or by in situ hybridisation for mRNA would permit the identification of cells responsible for their production and further elucidate the cellular and molecular changes occurring in tissues affected by GvHD. On the present evidence, however, extremely sensitive methods would be required. If cytokine production can be shown early in the course of the disease by these methods (even if only in a few cells), then it may have important diagnostic value in the stage before the histological picture becomes diagnostic. Further work on small biopsy specimens limiting PCR analysis to only one cytokine would be another approach to detecting minute quantities of cytokine RNA in early disease.

This work was supported by the Leukaemia Research Fund. We are grateful to Mrs Valerie Power for secretarial assistance.

1 Gale RP. Graft-versus-host disease. Immunol Rev 1985;88 193-214

2 Waldmann H, Hale G, Cividalli G, et al Elimination of graft-versus-host disease by in vitro depletion of alloreactive lymphocytes with a monoclonal rat anti-human lymphocyte antibody (Campath-1). Lancet 1984;ii: lymphocy.

3 Martin PJ, Hansen JA, Buckner CD, et al Effects of in vitro depletion of $\mathrm{T}$ cells in HLA-identical allogeneic marrow grafts. Blood 1985;66:664-72.

4 Apperley JF, Jones L, Hale G, et al. Bone marrow transplantation for patients with chronic myeloid leukaemia: T-cell depletion with Campath-1 reduces the incidence of graft-versus-host disease but may increase the risk of leukaemic relapse. Bone Marrow Transplant 1986;1: $53-66$.

5 Lerner KG, Kao GF, Storb R, Buckner CD, Clift RA, Thomas ED. Histopathology of graft-vs.-host reaction (GvHR) in human recipients of marrow from HLA-Amatched sibling donors. Transplant Proc 1974;6:367-71.

6 Elliott CJ, Sloane JP, Sanderson KV, Vincent M, Shepherd V, Powles R. The histological diagnosis of cutaneous graft versus host disease: relationship of skin changes to marrow purging and other clinical variables. changes to marrow purging and

7 Norton J, Sloane JP. Epidermal damage in skin of allogeneic marrow recipients: relative importance of chemotherapy, conditioning and graft versus host disease. Histopathology. 1992;21:529-34.

8 Lampert IA, Suitters AJ, Chisholm PM. Expression of Ia antigen on epidermal keratinocytes in graft-versus-host disease. Nature 1981;293:149-65.

9 Sloane JP, Elliott CJ, Powles R. HLA-DR expression in epidermal keratinocytes after allogeneic bone marrow transplantation. Transplantation 1988;46:840-4.

10 Norton J, Sloane JP. ICAM-1 expression on epidermal keratinocytes in cutaneous graft-versus-host disease. keratinocytes in cutaneous grantation 1991;51:1203-6.

11 Norton J, Sloane JP, Al-Saffar N, Haskard DO. Vessel associated adhesion molecules in normal skin and acute graft-versus-host disease. F Clin Pathol 1991;44:586-91.

12 Balkwill FM. Cytokines in cancer therapy. Oxford: Oxford University Press, 1989.

13 Meager A. Cytokines. Milton Keynes: Open University Press, 1990.

14 Henderson DC, Riches PG, Dadian G, Gooding R, Rowbottom AW, Trumen L. Cytokine and neopterin production in graft versus host disease inter-relationproduction in graft versus host disease inter-re

15 Cohen J, Bayston K. Lymphokines and the acute phase response in clinical bone marrow transplantation. European Cytokine Network 1990;1:251-3.

16 Dallman MJ, Larsen CP, Morris PJ. Cytokine gene transcription in vascularised organ grafts: analysis using semiquantitative polymerase chain reaction. $\mathcal{F}$ Exp Med 1991;174:493-6.

17 Dilly SA, Sloane JP, Psalti ISM. The cellular composition of human lymph nodes after allogeneic bone marrow transplantation: an immunohistological study. 7 Pathol 1986;150:213-21.

18 Dilly SA, Sloane JP. Cellular composition of the spleen after human allogeneic bone marrow transplantation. $f$ Pathol 1988;155:151-60.

19 Chomezynski P, Saachi N. Single step method of RNA isolation by acid guanidinium triocyanate-phenol-chloroform extraction. Analyt Biochem 1987;162:156-9.

20 Maniatis T, Fritsch EF, Sambrook J. Molecular cloning: $A$ laboratory manual. 2nd ed Cold Spring Harbour, New York: Cold Spring Harbour Laboratory Press, 1989.

21 Elliott CJ, Sloane JP, Pallett CD, Sanderson KV. Cutaneous leucocyte composition after human allogeneic bone marrow transplantation: relationship to marrow purging, histology and clinical rash. Histopathology 1988;12:1-16.

$22 \mathrm{Li} \mathrm{B}$, Sehajpal PK, Subramaniam A, Joseph A, Stenzel $\mathrm{KH}$, Suthanthiran $\mathrm{M}$. Inhibition of IL-2 receptor in normal human $T$ cells by cyclosporin. Demonstration at the mRNA, protein and functional level. Transplantation the mRNA, protein

23 Piguet P-F. Tumour necrosis factor and graft-vs-host disease. Haematology 1990;12:255-76.

24 Piguet P-F, Grau GE, Allet B, Vassalli P. Tumour necrosis factor/cachectin is an effector of skin and gut lesions of acute phase of graft-vs-host disease. 7 Exp Med 1987;166:1280-9.

25 Piguet P-F, Grau GE, Allet B, Kapanci Y, Vassalli P. Diffuse alveolar damage elicited by perfusion with tumour necrosis factor (TNF). Int Arch Allergy Immunol 1986;83:18.

26 Dustin ML, Singer KH, Tuck DT, Springer TA. Adhesion of T lymphoblasts to epidermal keratinocytes Adhesion of T lymphoblasts to epidermal keratinocytes is regulated by interferon $\gamma$ and is mediated by intercel-
lular adhesion molecule 1 (ICAM-1). f Exp Med 1988; lular adhesion

27 Thornhill MH, Wellicome SM, Mahiouz DL, Lanchbury JSS, Kyan-Aung U, Haskard DO. Tumor necrosis factor combines with IL-4 or IFN- $\gamma$ to selectively enhance endothelial cell adhesiveness for $\mathrm{T}$ cells. $\mathcal{f}$ Immunol 1991;146:592-8.

28 Pober JS, Bevilacqua MP, Mendrick DL, Lapierre LA, Fiers W, Gimbrone MA. Two distinct monokines, interleukin 1 , and tumour necrosis factor, each independently induce the biosynthesis and transient expression of the same antigen on the surface of cultured human of the same antigen on the surface of cultured huma

29 Symington FW. Lymphotoxin, tumor necrosis factor, and gamma interferon are cytostatic for normal human keratinocytes. F Invest Dermatol 1989;92:798-805. 